\title{
Seismic and Energetic Interventions on a Typical South Italy Residential Building: Cost Analysis and Tax Detraction
}

\section{OPEN ACCESS}

Edited by:

Panagiotis G. Asteris,

School of Pedagogical and Technological Education, Greece

Reviewed by:

Constantinos Repapis, University of West Attica, Greece

Prachand Man Pradhan,

Kathmandu University, Nepal

*Correspondence: Antonio Formisano antoform@unina.it

Specialty section:

This article was submitted to

Earthquake Engineering,

a section of the journal

Frontiers in Built Environment

Received: 04 November 2018

Accepted: 28 January 2019

Published: 22 February 2019

Citation:

Formisano A, Vaiano $G$ and Fabbrocino $F$ (2019) Seismic and Energetic Interventions on a Typical South Italy Residential Building: Cost

Analysis and Tax Detraction.

Front. Built Environ. 5:12.

doi: 10.3389/fbuil.2019.00012

\begin{abstract}
Antonio Formisano ${ }^{1 *}$, Generoso Vaiano ${ }^{1}$ and Francesco Fabbrocino ${ }^{2}$
${ }^{1}$ Department of Structures for Engineering and Architecture, University of Naples "Federico II", Naples, Italy, ${ }^{2}$ Department of Engineering, Pegaso University, Naples, Italy
\end{abstract}

Italian buildings are mainly represented by unreinforced masonry (URM) constructions, which were mostly built before 1970, often without respecting seismic design criteria. The main objective of Italian designers is, therefore, to retrofit these buildings in order to improve their safety under earthquake, as well as to preserve the memory of the ancient building art. In addition, the assessment of the building energetic efficiency is nowadays a very pressing need for designers and practitioners. Energetic efficiency represents the capacity to optimize the consumption of energy resources in order to reach prefixed requirements for the environment protection. This paper shows both seismic and energetic retrofitting interventions on a residential URM building typical of the constructive practice in the South Italy. Initially, the building characterization under geometrical and structural viewpoints is done. Subsequently, the seismic vulnerability verification is performed with unsatisfactory results, so requiring upgrading or retrofitting interventions. Moreover, with the aim to increase living comfort and energy efficiency, energetic upgrading interventions, aimed at decreasing the building transmittance, are proposed. Seismic and energetic interventions are then computed from the economic point of view in order to evaluate the financial contributions foreseen by the Italian 2018 Balance Law through the Sismabonus and Ecobonus tools, respectively. Finally, the study proposes a global performance index able to take into account contemporary the seismic, energetic, and economic benefits deriving from retrofitting interventions applied on the inspected residential building.

Keywords: masonry, seismic vulnerability, seismic retrofitting, energetic analysis, tax detraction, Sismabonus, Ecobonus

\section{INTRODUCTION}

Unreinforced masonry (URM) buildings represent a large portion of the Italian constructions. These structures were built largely in the first half of the 20th Century and were designed to resist gravity loads only, so without considering the effect of seismic loads. Vulnerability studies on this structural typology are carried out because during the past years also earthquakes having modest entity caused substantial damages with consequent human victims (D'Agostino et al., 2009; Michele et al., 2016). For this reason, modern Italian regulations consider Seismic Engineering as main branch of the Structural Engineering field, imposing analysis of new and existing buildings toward 
earthquakes (Italian Ministry of Infrastructures and Transports, 2008, 2009, 2018; Cecchi and Calvi, 2010). In particular, for existing structures the use of new techniques and materials for retrofitting has been implemented in the recent decades. With regard to masonry constructions, it is important to study their non-linear behavior in order to identify safety levels and structural problems. When performing seismic vulnerability assessment of masonry buildings, it is common pratice to study separately out-of-plane and in-plane mechanisms developed by seismic actions on the perimeter walls. In order to design the better retrofitting interventions in terms of resistance and costs, a great knowledge of the building dynamic behavior is required. Therefore, this study has encouraged many researchers who, starting from the observation of existing structures, have carried out numerical and experimental studies able to reflect the building real behavior subjected to static and dynamic loads. Regarding the experimental investigations, ambient vibration tests are the main methods for assessing the seismic behavior of full-scale structures (Krstevska et al., 2010; Clementi et al., 2017, 2018; Ubertini et al., 2017, 2018). Obtained results have been used as the basis for implementing different non-linear analysis methods (Tashkov et al., 2010; Brando et al., 2017; Quagliarini et al., 2017). Mostly, more accurate results have been obtained through the use of Finite Element (FE) models. However, also simplified models have been developed for the seismic vulnerability evaluation (Italian Ministry of Infrastructures and
Transports, 2018; Rapone et al., 2018). In particular, macroelements approach providing reliable and fast results have been successfully employed (Rapone et al., 2018). However, independently from the used analysis approach (numerical FE models, equivalent frame model, macro-elements model; theorical seismic analysis), modeling of masonry buildings is not a simple operation. The main difficulty is found in the material modeling. In fact, it is well-known that masonry is an orthotropic material having mechanical properties not

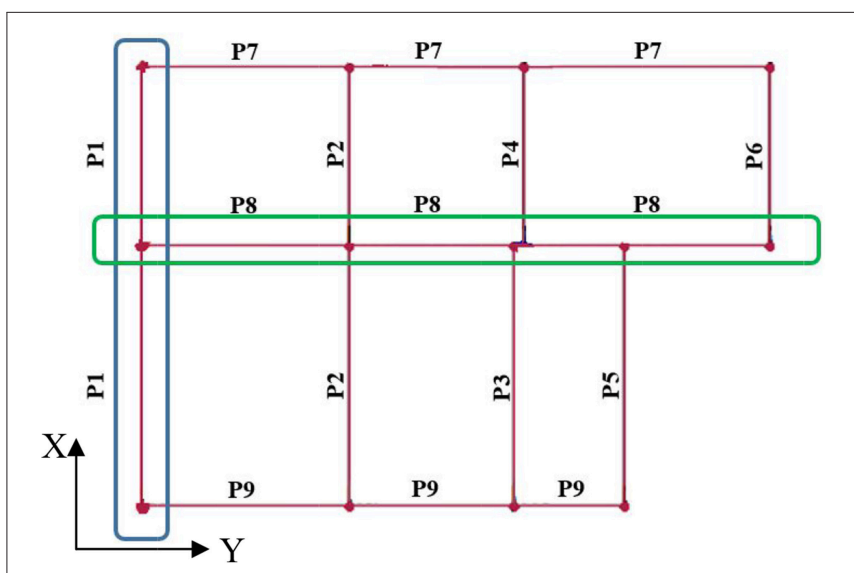

FIGURE 2 | Layout and numbering of masonry walls in the 3Muri model.

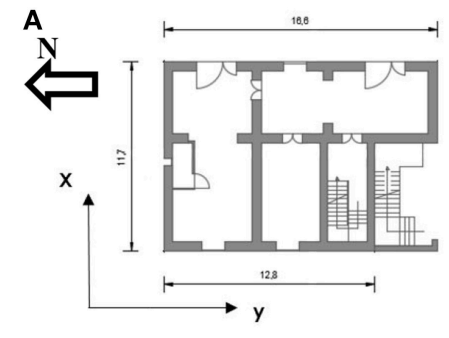

D



G

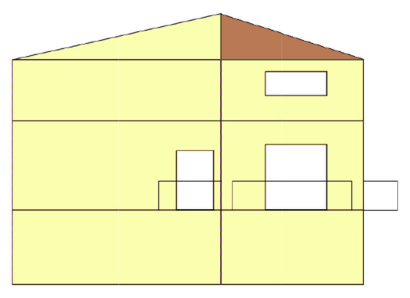

B

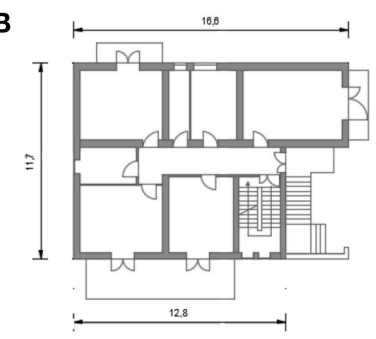

E

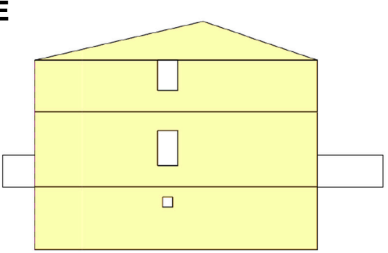

H

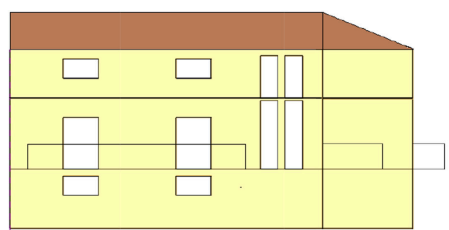

C



$\mathbf{F}$
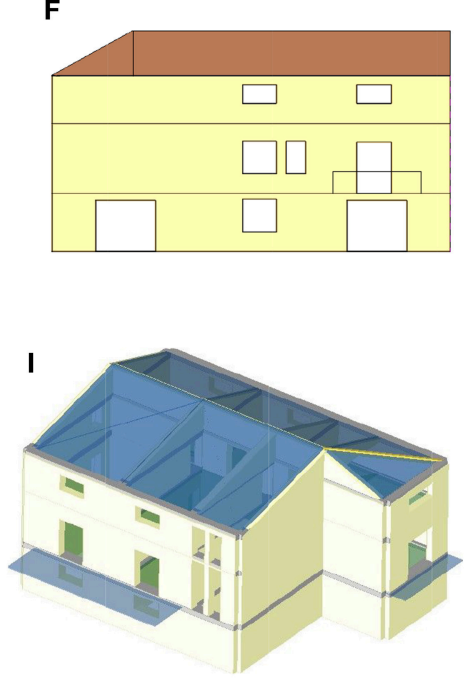

FIGURE 1 | Case study: First level (A), second level (B), third level (C), roof (D), north view (E), east view (F), south view (G), west view (H), and 3Muri model (I). 
constant throughout the whole walls (Marghella et al., 2016). In this framework, Italian code (Italian Ministry of Infrastructures and Transports, 2018) takes precautions considering proper building knowledge levels, which provide different safety coefficients depending on the number and type of on-site tests performed on masonry walls. Based on the results of seismic evaluation studies, it is very often required the seismic retroffiting or at least the seismic upgrading of masonry constructions. Therefore, in order to avoid building collapses and consequent human victims, over the years various traditional (Italian Ministers Council Presidency Decree (DPCM), 2011; Formisano, 2014, 2017; Formisano and Marzo,
2017) and innovative (Bertolesi et al., 2017; Mosoarca et al., 2017; Ramaglia et al., 2018) intervention techniques have been developed.

Another foundamental aspect to take into consideration is the building energy efficiency. In fact, masonry structures built in the past, before the promulgation of energetic regulations, have low thermal efficiency. Optimizing energetic performance gives rise to the improvement of winter and summer thermal comforts. Greatest energy consumptions occur due to the thermal dispersions through both the perimeter walls and the roof, where the energy upgrading interventions must be performed.

TABLE 1 | Pushover analysis results on the URM building.

\begin{tabular}{|c|c|c|c|c|c|c|}
\hline Analysis & Seismic direction & Seismic load & Eccentricity [cm] & $D_{\max }$ ULS [cm] & $D_{u}$ ULS [cm] & $\alpha_{U L S}$ \\
\hline 1 & $x$ & Proportional to masses & 0.00 & 2.30 & 1.89 & 0.860 \\
\hline 2 & $x$ & Proportional to first vibration mode & 0.00 & 2.80 & 1.62 & 0.644 \\
\hline 4 & $-X$ & Proportional to first vibration mode & 0.00 & 2.67 & 1.44 & 0.623 \\
\hline 5 & Y & Proportional to masses & 0.00 & 1.33 & 0.68 & 0.668 \\
\hline 8 & $-Y$ & Proportional to first vibration mode & 0.00 & 1.72 & 0.99 & 0.682 \\
\hline 9 & $x$ & Proportional to masses & 56.50 & 2.30 & 1.89 & 0.859 \\
\hline 10 & $x$ & Proportional to masses & -56.50 & 2.31 & 1.80 & 0.826 \\
\hline 11 & $x$ & Proportional to first vibration mode & 56.50 & 2.81 & 1.66 & 0.657 \\
\hline 12 & $x$ & Proportional to first vibration mode & -56.50 & 2.79 & 1.53 & 0.620 \\
\hline 13 & $-X$ & Proportional to masses & 56.50 & 2.20 & 1.17 & 0.642 \\
\hline 17 & Y & Proportional to masses & 81.00 & 1.42 & 0.77 & 0.686 \\
\hline 18 & $\mathbf{Y}$ & Proportional to masses & -81.00 & 1.24 & 0.59 & 0.647 \\
\hline 19 & $\mathrm{Y}$ & Proportional to first vibration mode & 81.00 & 1.78 & 1.13 & 0.726 \\
\hline 20 & Y & Proportional to first vibration mode & -81.00 & 1.55 & 0.95 & 0.720 \\
\hline 21 & $-Y$ & Proportional to masses & 81.00 & 1.43 & 0.76 & 0.681 \\
\hline 22 & $-Y$ & Proportional to masses & -81.00 & 1.26 & 0.63 & 0.667 \\
\hline 23 & $-Y$ & Proportional to first vibration mode & 81.00 & 1.81 & 1.08 & 0.696 \\
\hline 24 & $-Y$ & Proportional to first vibration mode & -81.00 & 1.60 & 0.94 & 0.700 \\
\hline
\end{tabular}

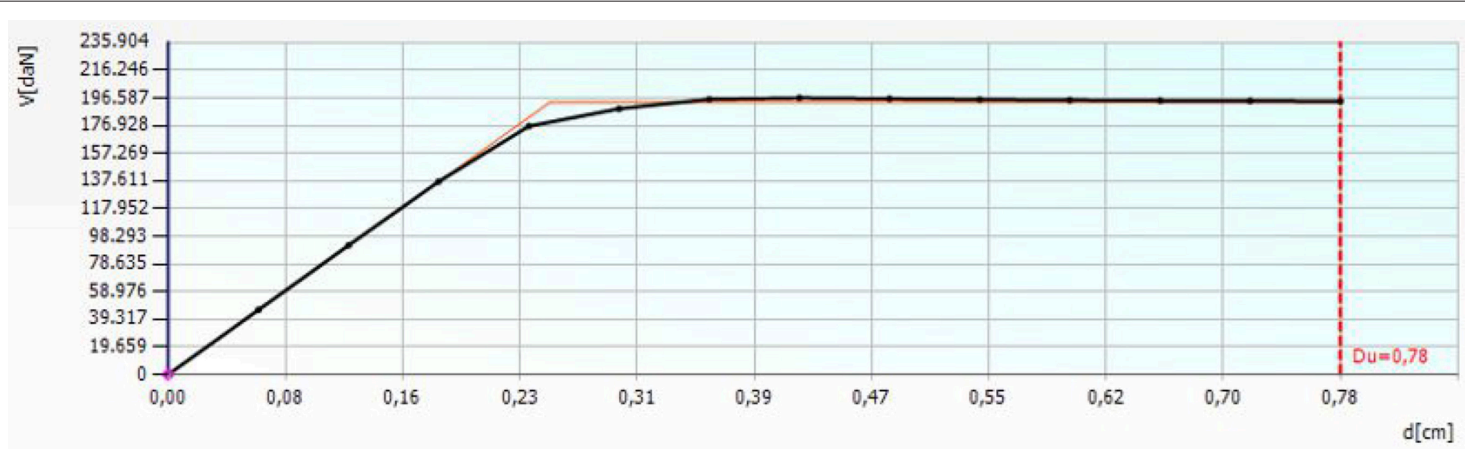

FIGURE 3 | Pushover curves resulting from analysis n.15. 

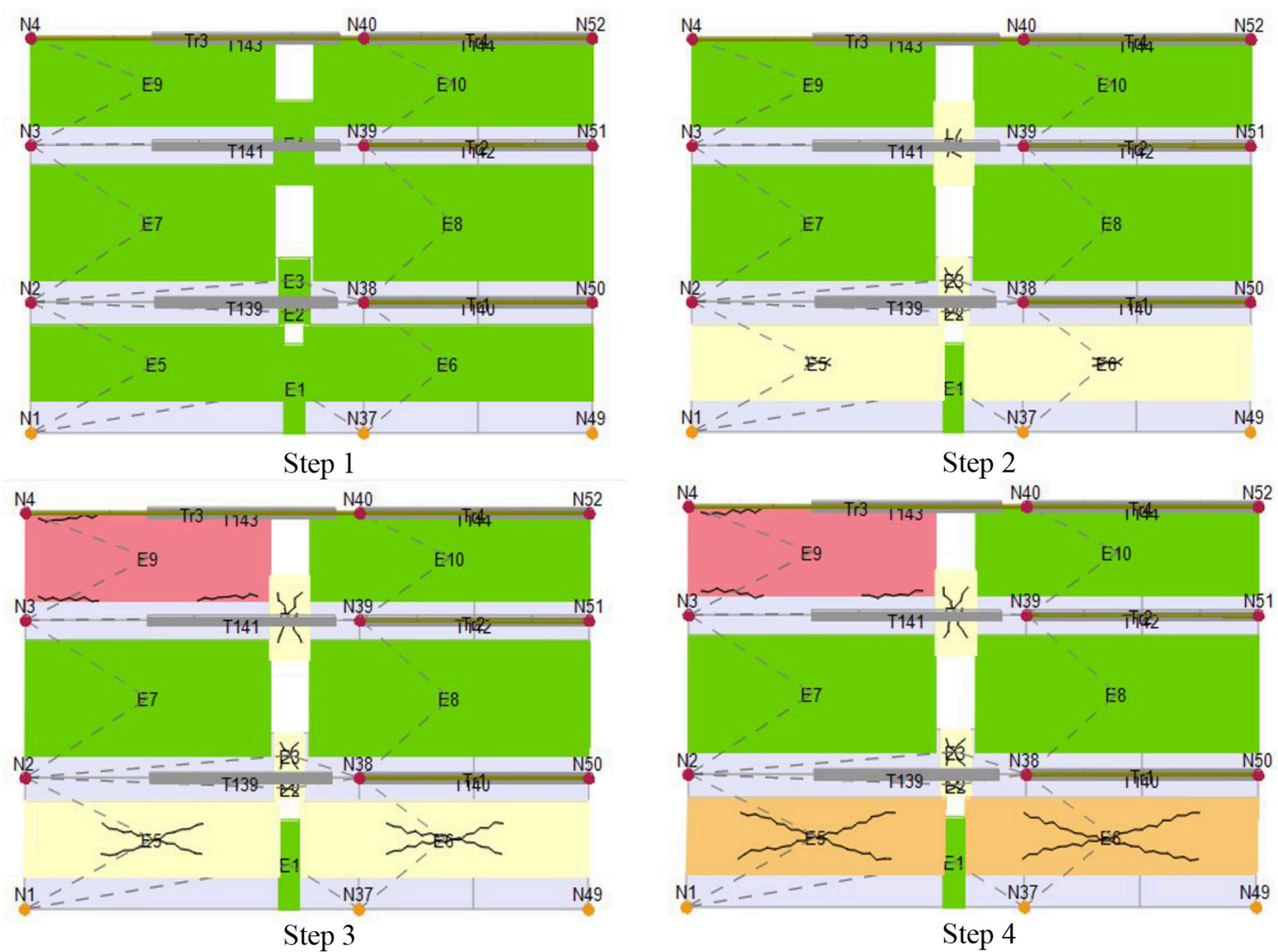

FIGURE 4 | Progressive damaging state of piers and spandrels of the P1 wall in the analysis n. 15 (green: no damage, pink: compression-bending moment plastic, light yellow: shear plastic, orange: shear failure).

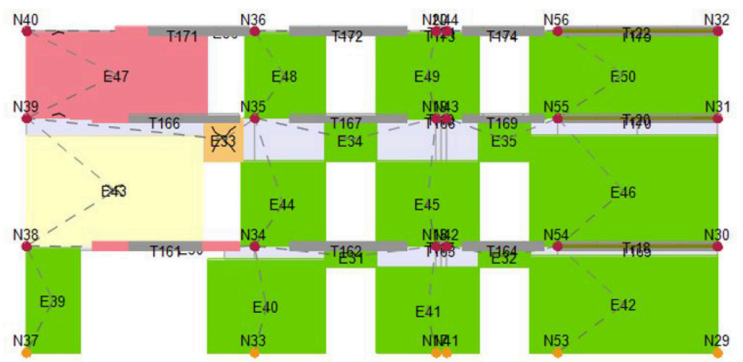

Step 1

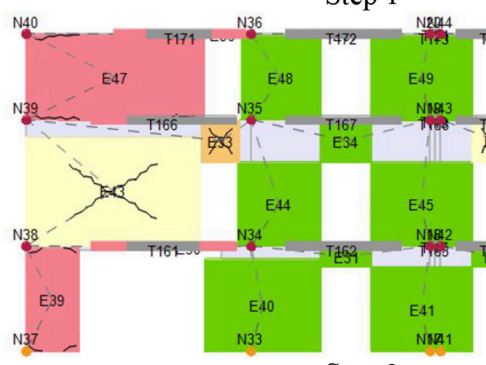

Step 3

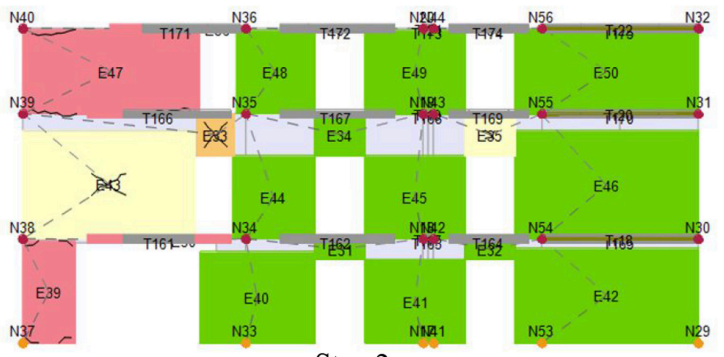

Step 2

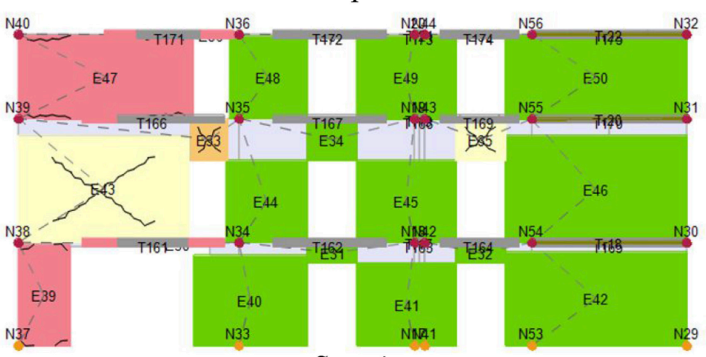

Step 4

FIGURE 5 | Progressive damaging state of piers and spandrels of the P8 wall in the analysis n. 15 (green: no damage, pink: compression-bending moment plastic, light yellow: shear plastic, orange: shear failure). 
In this paper a seismic, energetic, and economic combined procedure for retrofitting residential buildings is presented. The case study is a masonry residential building located in a small district of Avellino, which represents a typical example of the South Italy constructive practice. This building is placed in seismic zone 1 (Italian Ministry of Infrastructures and Transports, 2018) and climatic zone D.

Firstly, on the basis of numerical seismic analyses carried out by the 3Muri software, two different interventions (upgrading and retrofitting) are proposed by strengthening some structural walls with reinforced plaster. In particular, using the 3Muri software building, the seismic vulnerability through modal and static non-linear (pushover) analyses is evaluated. Pushover analyses allow to identify the most vulnerable structure parts and, therefore, the most appropriate seismic upgrading or retrofitting technique to intervene on the detected weak structural elements, taking into account the cost-benefit ratio, are designed.

Subsequently, after an energy efficiency study is carried out, two energetic upgrading interventions, concerning the isolation of perimeter walls and roof, are considered.

Finally, seismic and energetic interventions are economically computed in order to obtain a global performance index able to evaluate the effectiveness of interventions compared to the cost detractions offered by the Italian Government.

\section{THE CASE STUDY}

The case study is a masonry residential building located in Venticano, a district of Avellino (Italy) making part of the Irpinia basin, which was strongly damaged by the 1980 earthquake. The structure, built before 1970, was designed to resist gravity loads only. It develops on three levels having plan geometrical dimensions of $16.60 \times 11.70 \mathrm{~m}$ (Figure 1) and a total height of about $8 \mathrm{~m}$. Structural walls are made of tuff blocks and cement mortar. The three levels are connected to each other by an internal RC staircase. Both the external and internal staircase beams are made of reinforced concrete with $4 \Phi$ 12 longitudinal bars and $\Phi 8$ stirrups having pitch of $20 \mathrm{~cm}$. Smooth longitudinal bars and stirrups have FeB32k steel grade with yielding stress of $315 \mathrm{MPa}$ and ultimate stress of 490 $\mathrm{MPa}$. Intermediate and roof levels, connected to perimeter walls through RC tie-beams, are made of RC joists and hollow tiles. Masonry foundations are of continuous type and they extend at a depth of $1.70 \mathrm{~m}$ underground. Material properties are unknown, since any certifications and laboratory tests of the building construction period have not been recovered and no in-situ tests have been planned to be performed. The building access is on the east side and consists of two openings $(2.45 \times 2.20$ meters $)$, one of which is accessible by cars.

\section{SEISMIC VULNERABILITY ASSESSMENT Numerical Analysis on the URM Building Model}

The seismic vulnerability evaluation is carried out on the basis of non-linear static analyses performed by means of the 3Muri software (S.T.A.DATA, 2016). The implemented macroelement model of the building is depicted in Figure 1I. In this calculation program, with reference to the Ultimate Limit State (ULS) (Italian Ministry of Infrastructures and Transports, 2018), the risk coefficient $\alpha_{U L S}$ can be calculated. The generic $\alpha_{\text {ULS }}$ coefficient is the ratio between the ground acceleration leading toward the attainment of the ULS and the corresponding Peak Ground Acceleration (PGA) related to the building reference return period. In particular, $24 \alpha_{\text {ULS }}$ coefficient values, corresponding to 24 pushover analyses different for direction ( $\mathrm{X}$ and $\mathrm{Y}$ ), seismic forces distribution (proportional to masses or first vibration mode) and relative position between centroid

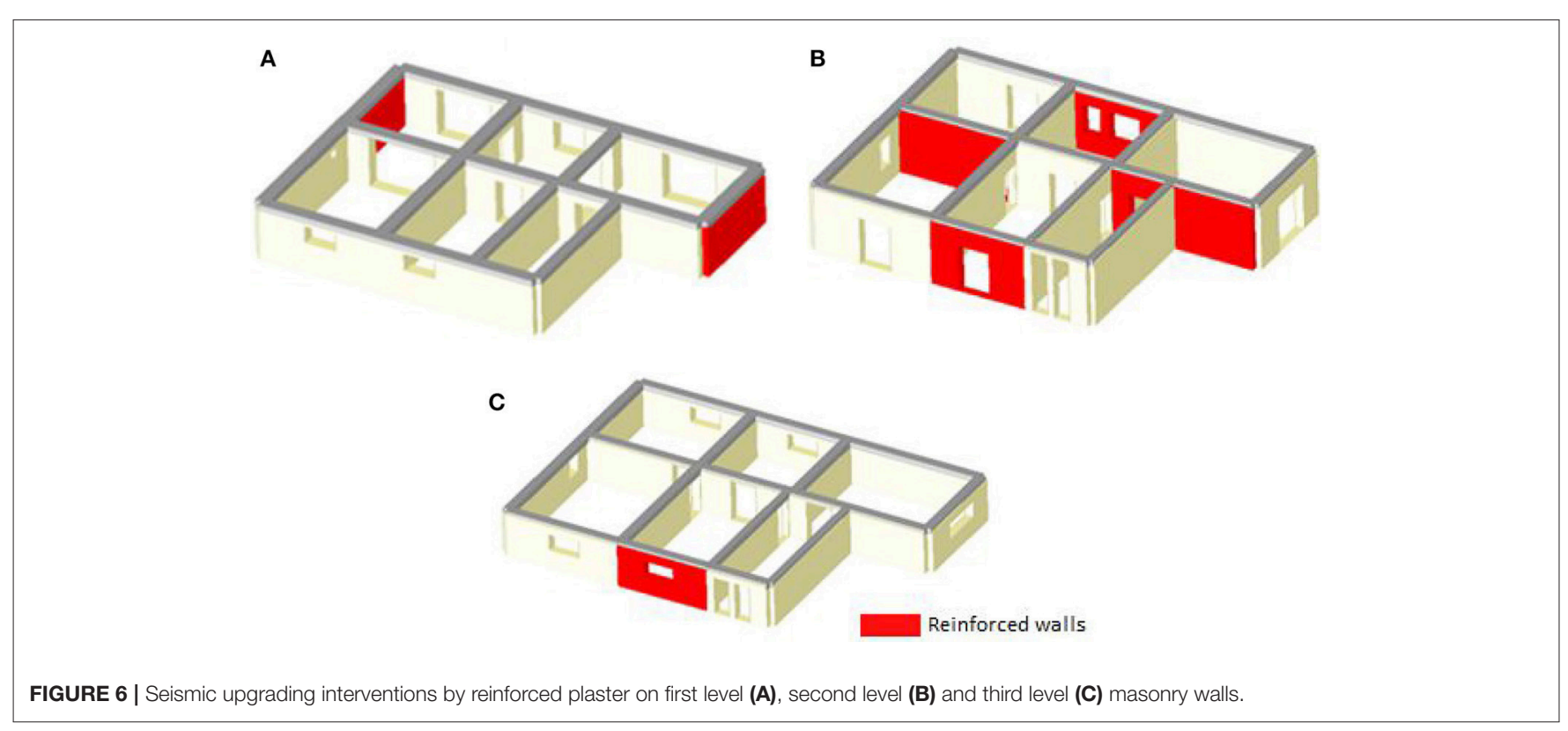


and stiffness center (with eccentricity or not), are obtained. $\alpha_{\text {ULS }} \geq 1$ corresponds to a satisfactory seismic response, with the structure that does not exhibit significant damages. On the other hand, $\alpha_{\text {ULS }}<1$ is representative of an unsatisfied

TABLE 2 | Pushover analysis results for seismic upgrading of the URM building.

\begin{tabular}{|c|c|c|c|c|c|c|}
\hline Analysis & Seismic direction & Seismic load & Eccentricity [cm] & $\mathrm{D}_{\max }$ ULS [cm] & $\mathrm{D}_{\mathrm{u}}$ ULS $[\mathrm{cm}]$ & $\alpha U L S$ \\
\hline 1 & $x$ & Proportional to masses & 0.00 & 1.60 & 1.44 & 0.920 \\
\hline 2 & $x$ & Proportional to first vibration mode & 0.00 & 1.87 & 1.03 & 0.628 \\
\hline 3 & $-X$ & Proportional to masses & 0.00 & 1.54 & 0.86 & 0.659 \\
\hline 4 & $-X$ & Proportional to first vibration mode & 0.00 & 1.78 & 1.08 & 0.680 \\
\hline 5 & Y & Proportional to masses & 0.00 & 1.05 & 1.39 & 1.207 \\
\hline 6 & Y & Proportional to first vibration mode & 0.00 & 1.38 & 1.03 & 0.818 \\
\hline 7 & $-Y$ & Proportional to masses & 0.00 & 1.06 & 1.58 & 1.308 \\
\hline 8 & $-\mathrm{Y}$ & Proportional to first vibration mode & 0.00 & 1.41 & 0.99 & 0.779 \\
\hline 9 & $x$ & Proportional to masses & 56.50 & 1.62 & 1.48 & 0.935 \\
\hline 10 & $x$ & Proportional to masses & -56.50 & 1.61 & 1.39 & 0.895 \\
\hline 11 & $x$ & Proportional to first vibration mode & 56.50 & 1.87 & 1.03 & 0.626 \\
\hline 12 & $x$ & Proportional to first vibration mode & -56.50 & 1.86 & 1.03 & 0.631 \\
\hline 13 & $-X$ & Proportional to masses & 56.50 & 1.56 & 0.90 & 0.676 \\
\hline 14 & $-X$ & Proportional to masses & -56.50 & 1.54 & 0.86 & 0.660 \\
\hline 15 & $-X$ & Proportional to first vibration mode & 56.50 & 1.79 & 1.08 & 0.677 \\
\hline 16 & $-X$ & Proportional to first vibration mode & -56.50 & 1.79 & 1.08 & 0.679 \\
\hline 17 & Y & Proportional to masses & 81.00 & 1.12 & 1.44 & 1.181 \\
\hline 18 & Y & Proportional to masses & -81.00 & 0.99 & 1.21 & 1.143 \\
\hline 19 & Y & Proportional to first vibration mode & 81.00 & 1.48 & 1.08 & 0.799 \\
\hline 20 & Y & Proportional to first vibration mode & -81.00 & 1.28 & 0.90 & 0.788 \\
\hline 21 & $-Y$ & Proportional to masses & 81.00 & 1.14 & 1.40 & 1.146 \\
\hline 22 & $-\mathrm{Y}$ & Proportional to masses & -81.00 & 0.99 & 1.49 & 1.314 \\
\hline 23 & $-Y$ & Proportional to first vibration mode & 81.00 & 1.53 & 1.04 & 0.757 \\
\hline 24 & $-Y$ & Proportional to first vibration mode & -81.00 & 1.32 & 0.90 & 0.768 \\
\hline
\end{tabular}
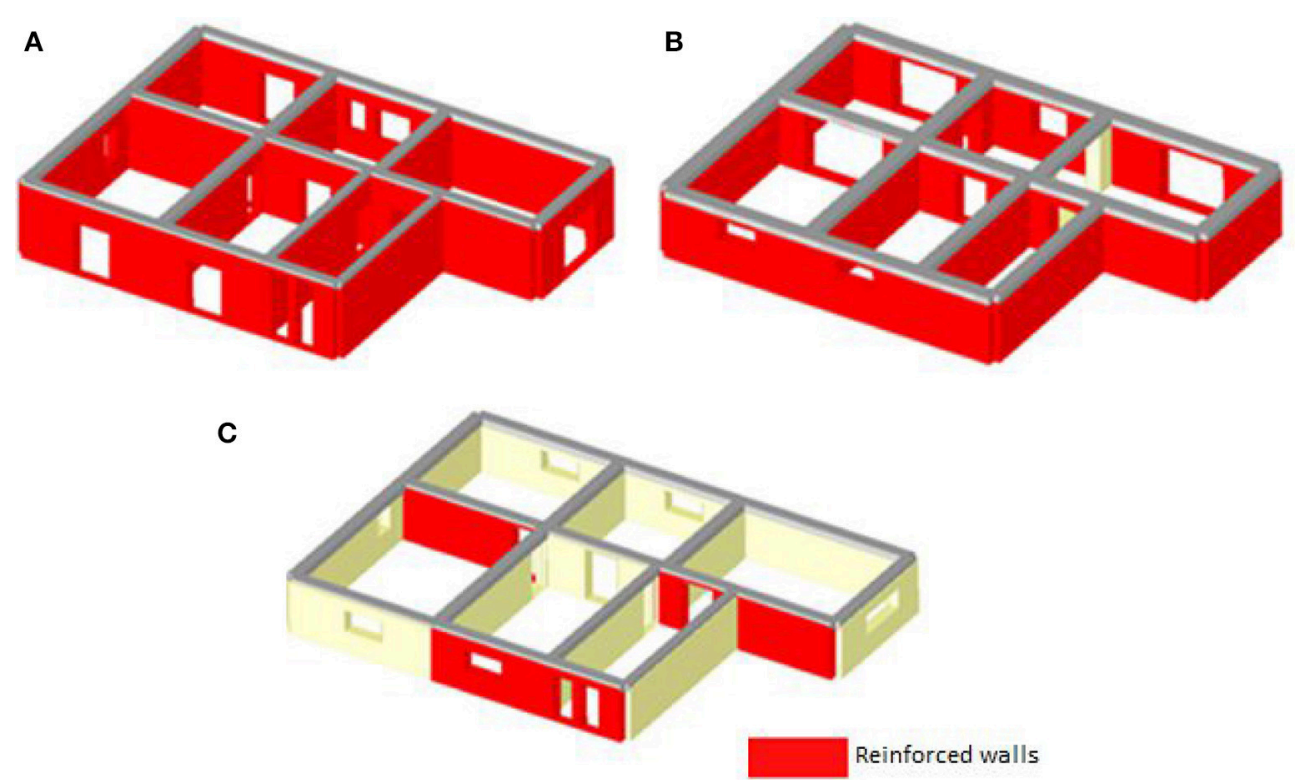

FIGURE 7 | Seismic retrofitting interventions by reinforced plaster on first level (A), second level (B), and third level (C) masonry walls. 
seismic check, so that anti-seismic interventions are required. In this case, after the design of seismic interventions is carried out, the seismic risk coefficient is re-evaluated. If $\alpha_{U L S} \geq 1$, the seismic retrofitting is reached, while if $\alpha_{U L S}<1$, but it is higher than the starting value, the seismic upgrading is achieved.

Initially, the original URM building model, whose walls are arranged according to the layout of Figure 2, is analyzed.

Performed pushover analyses provide $\alpha_{U L S}$ values lower than one (Table 1). In particular, the lowest values are 0,610 (analysis n. 15) and 0,647 (analysis n. 18) in directions $X$ and $\mathrm{Y}$, respectively.

Following the used procedure and for the sake of example, the analysis results deriving from the analysis n. 15 are herein discussed. As illustrated in Figure 3, when this pushover analysis is performed 2 types of curves are achieved. The first curve (black color) provides the Multi-degree of freedom (MDOF) structure capacity, while the second one (orange color) represents the equivalent Single degree of freedom (SDOF) system capacity. The building is able to resist seismic loads if Dmax (seismic demand displacement) is lower than $\mathrm{Du}$ (structure ultimate displacement).

From pushover analysis the behavior of the walls under seismic actions is also noticed. In fact,

piers and spandrels of walls are characterized by different colors depending on both their state (no damage, plastic or failure) and the stress causing the structural damage (shear or compression-bending moment). These indications allow to choose and locate the upgrading (or retrofitting) interventions.

With reference to the Figure 2, two different walls, namely $\mathrm{P} 1$ in direction $\mathrm{Y}$ and $\mathrm{P} 8$ in direction $\mathrm{X}$, have been monitored step-by-step in terms of damaging state up to collapse under the considered pushover analysis (see Figures 4, 5). In particular, it is noticed that piers and spandrels change progressively color

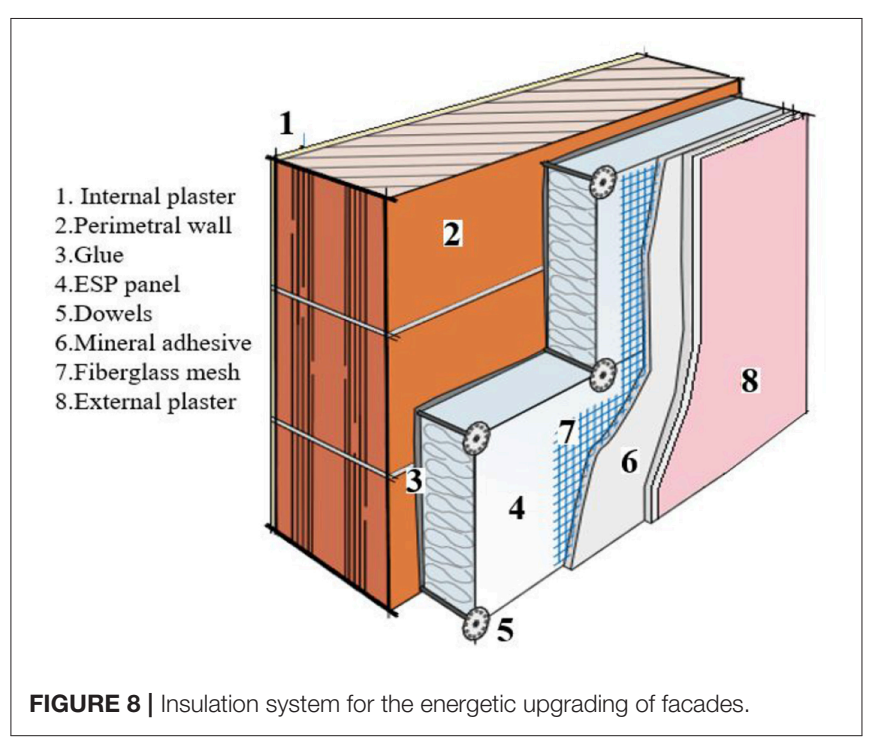

TABLE 3 | Pushover analysis results for seismic retrofitting of the URM building.

\begin{tabular}{|c|c|c|c|c|c|c|}
\hline Analysis & Seismic direction & Seismic load & Eccentricity [cm] & $\mathrm{D}_{\max }$ ULS [cm] & $\mathrm{D}_{\mathrm{u}}$ ULS $[\mathrm{cm}]$ & $\alpha_{\text {ULS }}$ \\
\hline 1 & $x$ & Proportional to masses & 0.00 & 0.95 & 1.39 & 1.198 \\
\hline 2 & $x$ & Proportional to first vibration mode & 0.00 & 1.32 & 1.93 & 1.241 \\
\hline 3 & $-X$ & Proportional to masses & 0.00 & 0.89 & 1.40 & 1.231 \\
\hline 4 & $-X$ & Proportional to first vibration mode & 0.00 & 1.16 & 1.89 & 1.296 \\
\hline 5 & Y & Proportional to masses & 0.00 & 0.60 & 1.21 & 1.833 \\
\hline 6 & Y & Proportional to first vibration mode & 0.00 & 0.79 & 1.62 & 1.722 \\
\hline 7 & $-\mathrm{Y}$ & Proportional to masses & 0.00 & 0.52 & 1.13 & 1.874 \\
\hline 8 & $-Y$ & Proportional to first vibration mode & 0.00 & 0.71 & 1.49 & 1.674 \\
\hline 9 & $x$ & Proportional to masses & 56.50 & 0.90 & 1.44 & 1.241 \\
\hline 10 & $x$ & Proportional to masses & -56.50 & 0.98 & 1.39 & 1.182 \\
\hline 11 & $x$ & Proportional to first vibration mode & 56.50 & 1.31 & 1.93 & 1.248 \\
\hline 12 & $x$ & Proportional to first vibration mode & -56.50 & 1.37 & 1.93 & 1.219 \\
\hline 13 & $-X$ & Proportional to masses & 56.50 & 0.87 & 1.35 & 1.222 \\
\hline 14 & $-X$ & Proportional to masses & -56.50 & 0.92 & 1.44 & 1.236 \\
\hline 15 & $-X$ & Proportional to first vibration mode & 56.50 & 1.14 & 1.80 & 1.272 \\
\hline 16 & $-X$ & Proportional to first vibration mode & -56.50 & 1.21 & 1.94 & 1.285 \\
\hline 17 & Y & Proportional to masses & 81.00 & 0.68 & 1.71 & 1.962 \\
\hline 18 & Y & Proportional to masses & -81.00 & 0.51 & 0.81 & 1.579 \\
\hline 19 & Y & Proportional to first vibration mode & 81.00 & 0.86 & 1.62 & 1.590 \\
\hline 20 & Y & Proportional to first vibration mode & -81.00 & 0.70 & 1.53 & 1.771 \\
\hline 21 & $-\mathrm{Y}$ & Proportional to masses & 81.00 & 0.62 & 1.44 & 1.951 \\
\hline 22 & $-Y$ & Proportional to masses & -81.00 & 0.49 & 0.95 & 1.828 \\
\hline 23 & $-\mathrm{Y}$ & Proportional to first vibration mode & 81.00 & 0.78 & 1.62 & 1.595 \\
\hline 24 & $-Y$ & Proportional to first vibration mode & -81.00 & 0.65 & 1.53 & 1.803 \\
\hline
\end{tabular}


according to their degradation level. In addition, from analysis results it is possible to visualize the percentages of elements exhibiting failure, that are equal to 26.82 and $1.10 \%$ for P1 and P8 walls, respectively.

From pushover analysis it is shown that in the P1 wall the collapse mechanism is the shear failure of the first level piers, which is achieved when the second level is undamaged (Figure 4). Instead, in the P8 wall only the left side is damaged with compression-bending moment plastic behavior of piers at the first and third levels and by shear mechanisms into one pier and one spandrel at the second level (Figure 5).

\section{Seismic Upgrading and Retrofitting Results}

Based on the achieved results on the original URM building model, firstly seismic upgrading interventions are performed by applying reinforced plaster on 7 walls (Figure 6).

Reinforced plaster technique is a process used to reinforce existing masonry buildings by applying a net of steel bars, connected to each other by metal connectors and covered by a cement mortar plaster layer, on the two wall sides. The main advantages of this reinforcing technique, which gives rise to the increase of the masonry wall thickness, are:

- Improvement of masonry mechanical characteristics due to the masonry confinement effect;

- Introduction of tensile-resistant structural elements, i.e., steel bars, since ordinary masonry has a very low tensile resistance;
In the case under study a $4 \mathrm{~cm}$ cement mortar plaster layers (density of $16 \mathrm{kN} / \mathrm{m} 3$ ) and a $10 \times 10 \mathrm{~cm}$ net of $\Phi 8$ bars made of B450C steel are applied on both sides of masonry walls revealing crisis conditions.

From numerical investigation results it is seen that 6 of 24 pushover analyses show $\alpha_{\text {ULS }}$ values $>1$ (Table 2). The minimum increase of these coefficients with respect to those of the URM model is equal to 1.77 and $8.76 \%$ in directions $\mathrm{X}$ and $\mathrm{Y}$, respectively. Later on, the building seismic retrofitting is reached by reinforcing with reinforced plaster the masonry walls illustrated in Figure 7. In this case, all pushover analyses give $\alpha_{U L S}$ values $>1$, with lowest values of 1.18 and 1.99 in directions $\mathrm{X}$ and $\mathrm{Y}$, respectively (Table 3 ). Comparing these results to those of the URM model, the minimum growth of the $\alpha_{\mathrm{ULS}}$ coefficient is $39.30 \%$ and $119.01 \%$ in directions $\mathrm{X}$ and Y, respectively.

\section{ENERGETIC UPGRADING}

\section{Premise}

The energy consumption of an ordinary building due to the summer and winter climatization is about half of the consumed total energy. Other notable energy losses can to be found in water heating and lighting. There are two methods to improve the thermal efficiency of a structure. The first is to intervene on the building structural elements, applying insulating materials. The second method consists in improving the energy efficacy of the building without operating on its structural parts. This
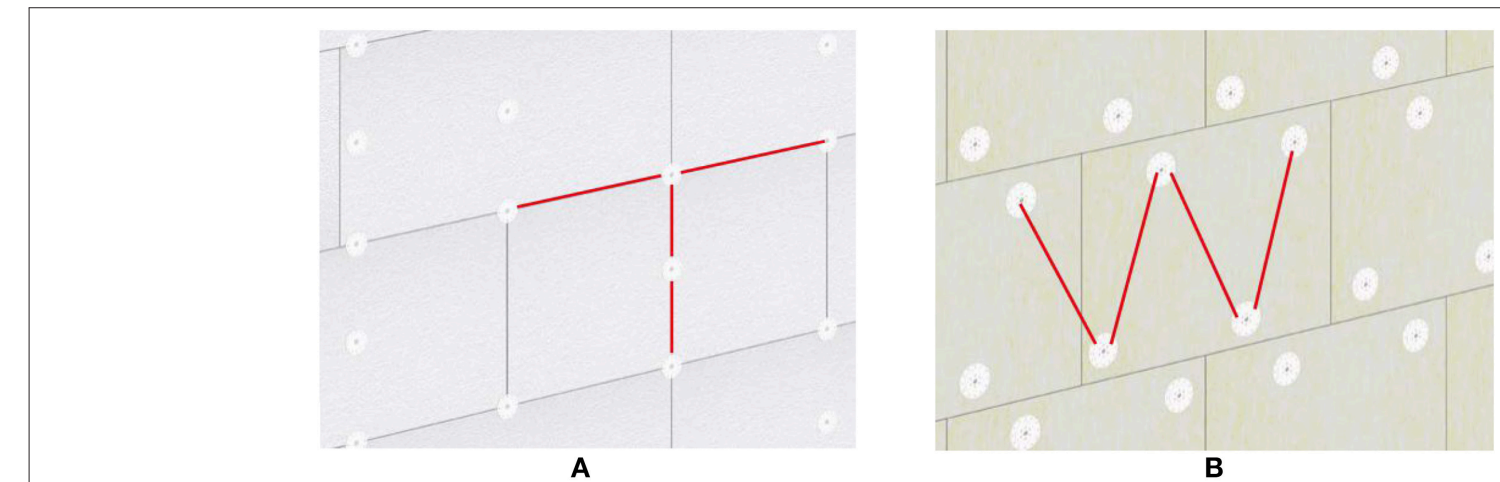

FIGURE 9 | Positioning of polystyrene sheets on the wall: "T" scheme (A); "W" scheme (B).

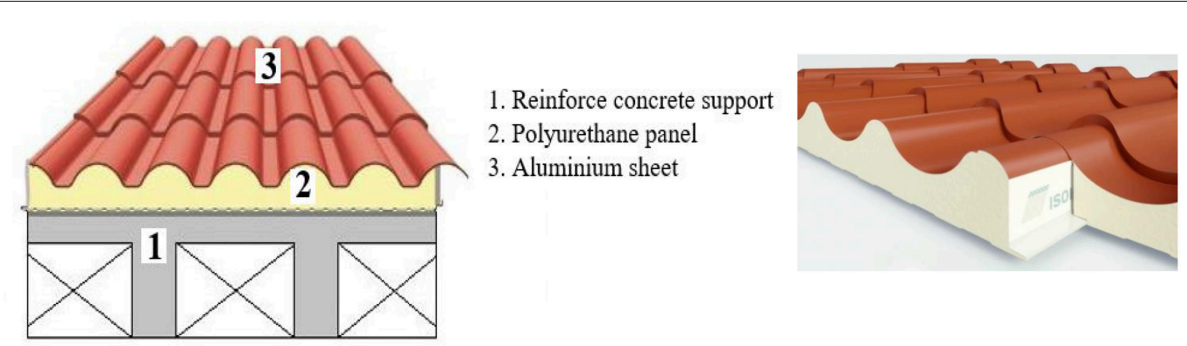

FIGURE 10 | Roof energetic upgrading through a new insulation system. 
is achieved optimizing the heating, ventilation, and conditioning systems (Xu et al., 2012; Jung et al., 2013), changing the windows and/or doors and so on. Obviously, a combination of the two methods can represent the ideal thermal upgrading solution.

Historic masonry buildings exhibit great energy loss and poor insulation. Referring to the two methods previously discussed, the post-insulation of the perimeter walls, since they represent the major part of the building enclosure area, is certainly the most effective energy upgrading solution, so ensuring the thermal comfort with adequate insulation levels (Aste et al., 2012; Roberts and Stephenson, 2012). Internal thermal upgrading intervention is probably the most economical solution and anyway ensures high thermal performance (Ueno and Van Straaten, 2012; Fumo et al., 2018).

The main issue studied in this paper is the energetic efficiency analysis of the examined building, which nowadays represents a very pressing matter for designers. With the aim to increase both the living comfort and the capacity to optimize the exploitation of energetic resources to reach a prefixed energetic requirement, thermal insulation interventions are designed to reduce the spread of heat through the building envelope. The energetic upgrading interventions are herein implemented on both perimeter walls and roof. With regard to perimeter walls, a façade insulation system based on prefabricated insulating elements to be applied on their external parts are designed. Instead, concerning the roof, the energetic upgrading intervention consists on the installation of polyurethane sandwich panels. Both interventions are explained in detail in the next sections.

\section{Façade Insulation System}

On the examined structure, a facade insulation method consisting of an external thermal system based on prefabricated insulating elements is used (Figure 8). Each panel is characterized by a specific insulating power expressed through the constitutive material conductivity. Conductivity is the ability of a building product to trasmit heat. Great values of conductivity correspond to a low insulating power. Generally, these insulation systems allow to reach extremely low thermal transmittance values in order to eliminate thermal bridgings and to provide multiple advantages from the economic point of view. In particular, they allow to obtain a high attenuation of the thermal flow and a greater temporal offset, so that heat peaks occurred during the hottest hours of the afternoon arrive inside the building in the cooler hours, when heat can be more easily dissipated thanks to the air ventilation of rooms through windows.

The herein proposed thermal insulation is applied directly to the external plaster of the existing building, which must be free from humidity problems. The first phase consists on fixing of metal profiles placed at the base of the external walls for the building entire perimeter. Afterward, glue is applied directly on expanded polystyrene sheets which are positioned on the wall. The positioning is done by offset rows, which are fixed by synthetic material inserts following the " $\mathrm{T}$ " or "W" scheme (Figure 9). Therefore, a smoothing layer is applied to ensure both the homogeneous and complete panels covering and the subsequent placement of the fiberglass mesh. Rows must be pressed punctually on the wall surface and positioned taking care to have a superposition of at least $10 \mathrm{~cm}$ between two layers. Finally, the finishing layer complete the wall energetic upgrading intervention. The benefit deriving from this intervention is estimated by comparing the transmittance value of the URM building with that of the energetically upgraded building. So, in this case, it is noticed that the transmittance parameter $\mathrm{U}_{0}=1.86 \mathrm{~W} / \mathrm{m}^{2} \mathrm{~K}$ for the URM building becomes $U_{1}=0.34 \mathrm{~W} / \mathrm{m}^{2} \mathrm{~K}$ after the performed intervention with a significant value decrease of $81.70 \%$.

\section{Roof Energetic Upgrading}

The energy improvement design is completed with the roof insulation through the application of polyurethane panels (Figure 10). This insulation typology is chosen for both

TABLE 4 | Seismic upgrading interventions costs.

\begin{tabular}{|c|c|c|c|c|c|c|c|c|c|c|}
\hline \multirow[t]{2}{*}{ Level } & \multirow[t]{2}{*}{ Activity } & \multirow[t]{2}{*}{ ID } & \multirow[t]{2}{*}{ Measurement unit } & \multicolumn{4}{|c|}{ Dimensions } & \multirow[t]{2}{*}{ Quantity [m²] } & \multicolumn{2}{|c|}{ Price } \\
\hline & & & & $\begin{array}{l}\text { Length } \\
\text { [m] }\end{array}$ & $\begin{array}{c}\text { Thickness } \\
\text { [m] }\end{array}$ & $\begin{array}{l}\text { Height } \\
\text { [m] }\end{array}$ & $\begin{array}{c}\text { Openings } \\
{\left[\mathrm{m}^{2}\right]}\end{array}$ & & $\begin{array}{l}\text { Unitary } \\
\text { [Euro] }\end{array}$ & $\begin{array}{l}\text { Total } \\
\text { [Euro] }\end{array}$ \\
\hline & Mobile scaffolding & & $\mathrm{m}^{2}$ & - & - & - & - & 150 & 10.12 & 1518.00 \\
\hline \multirow[t]{2}{*}{1} & Reinforced & Wall P2 & $\mathrm{m}^{2}$ & 4.45 & 0.55 & 2.50 & - & $2 \times 11.13$ & 68.51 & 1525.03 \\
\hline & plaster & Wall P8 & & 4.45 & 0.55 & 2.50 & - & $2 \times 11.13$ & & 1525.03 \\
\hline \multirow[t]{4}{*}{2} & & Wall P10 & & 4.50 & 0.40 & 3.00 & 3.08 & $2 \times 10.42$ & & 1427.74 \\
\hline & & Wall P12 & & 5.35 & 0.40 & 3.00 & 1.80 & $2 \times 14.25$ & & 1952.54 \\
\hline & & Wall P14 & & 6.60 & 0.40 & 3.00 & 1.80 & $2 \times 18.00$ & & 2466.36 \\
\hline & & Wall P16 & & 4.25 & 0.40 & 3.00 & 3.08 & $2 \times 9.67$ & & 1324.98 \\
\hline 3 & & Wall P16 & & 4.25 & 0.40 & 2.05 & 1.12 & $2 \times 7.566 / 9$ & & 1040.32 \\
\hline
\end{tabular}


performance characteristics and easiness of installation. The support structures and the relative panels fixing devices must be adequately sized and must meet safety, stability, and functionality requirements. The insulated sandwich panels, consisting of two metal plates joined by a layer of insulating material (polyurethane or rock wool), have the feature of resisting to shocks, bad weather,

TABLE 5 | Seismic retrofitting interventions costs.

\begin{tabular}{|c|c|c|c|c|c|c|c|c|c|c|}
\hline \multirow[t]{2}{*}{ Level } & \multirow[t]{2}{*}{ Activity } & \multirow[t]{2}{*}{ ID } & \multirow[t]{2}{*}{ Measurement unit } & \multicolumn{4}{|c|}{ Dimensions } & \multirow{2}{*}{$\begin{array}{c}\text { Quantity } \\
{\left[\mathrm{m}^{2}\right]}\end{array}$} & \multicolumn{2}{|c|}{ Price } \\
\hline & & & & $\begin{array}{l}\text { Length } \\
\text { [m] }\end{array}$ & $\begin{array}{c}\text { Thickness } \\
\text { [m] }\end{array}$ & $\begin{array}{c}\text { Height } \\
\text { [m] }\end{array}$ & $\begin{array}{c}\text { Openings } \\
{\left[\mathrm{m}^{2}\right]}\end{array}$ & & $\begin{array}{l}\text { Unitary } \\
\text { [Euro] }\end{array}$ & $\begin{array}{c}\text { Total } \\
\text { [Euro] }\end{array}$ \\
\hline & Scaffolding & Second level & $m^{2}$ & 45.63 & - & 5.50 & - & 500 & 17.62 & 8810.00 \\
\hline & & Third level & & 10.98 & - & 7.55 & - & 166 & & 2924.92 \\
\hline \multirow[t]{11}{*}{1} & Reinforced plaster & Wall P1 & $m^{2}$ & 11.70 & 0.55 & 2.50 & 0.16 & $2 \times 29.09$ & 68.51 & 3985.91 \\
\hline & & Wall P2 & & 10.60 & 0.55 & 2.50 & 2.40 & $2 \times 24.10$ & & 3302.18 \\
\hline & & Wall P3 & & 6.15 & 0.55 & 2.50 & - & $2 \times 15.38$ & & 2106.68 \\
\hline & & Wall P5 & & 6.70 & 0.55 & 2.50 & - & $2 \times 16.75$ & & 2295.09 \\
\hline & & Wall P6 & & 5.00 & 0.55 & 2.50 & - & $2 \times 12.50$ & & 1712.75 \\
\hline & & Wall P7 & & 16.60 & 0.55 & 2.50 & 12.74 & $2 \times 28.76$ & & 3940.70 \\
\hline & & Wall P8 & & 4.80 & 0.55 & 2.50 & 7.20 & $2 \times 4.80$ & & 657.70 \\
\hline & & Wall P9 & & 3.80 & 0.55 & 2.50 & 2.40 & $2 \times 7.10$ & & 972.84 \\
\hline & & Wall P10 & & 5.80 & 0.55 & 2.50 & 2.40 & $2 \times 12.10$ & & 1657.94 \\
\hline & & Wall P11 & & 5.60 & 0.55 & 2.50 & 1.12 & $2 \times 12.88$ & & 1764.82 \\
\hline & & Wall P12 & & 7.20 & 0.55 & 2.50 & 1.12 & $2 \times 16.88$ & & 2312.90 \\
\hline \multirow[t]{12}{*}{2} & & Wall P1 & & 11.70 & 0.40 & 3.00 & 1.12 & $2 \times 33.98$ & & 4655.94 \\
\hline & & Wall P2 & & 10.90 & 0.40 & 3.00 & 1.80 & $2 \times 30.90$ & & 4233.92 \\
\hline & & Wall P3 & & 6.30 & 0.40 & 3.00 & 1.80 & $2 \times 17.10$ & & 2343.04 \\
\hline & & Wall P4 & & 4.20 & 0.40 & 3.00 & - & $2 \times 12.60$ & & 1726.45 \\
\hline & & Wall P5 & & 6.70 & 0.40 & 3.00 & - & $2 \times 20.10$ & & 2754.10 \\
\hline & & Wall P6 & & 5.00 & 0.40 & 3.00 & 4.40 & $2 \times 10.60$ & & 1452.41 \\
\hline & & Wall P7 & & 16.60 & 0.40 & 3.00 & 6.16 & $2 \times 43.64$ & & 5979.55 \\
\hline & & Wall P8 & & 4.95 & 0.40 & 3.00 & 1.80 & $2 \times 13.05$ & & 1788.11 \\
\hline & & Wall P9 & & 4.10 & 0.40 & 3.00 & 1.80 & $2 \times 10.50$ & & 1438.71 \\
\hline & & Wall P10 & & 5.95 & 0.40 & 3.00 & 1.80 & $2 \times 16.05$ & & 2199.17 \\
\hline & & Wall P11 & & 5.55 & 0.40 & 3.00 & 3.08 & $2 \times 13.57$ & & 1859.36 \\
\hline & & Wall P12 & & 7.25 & 0.40 & 3.00 & 7.14 & $2 \times 14.61$ & & 2001.86 \\
\hline \multirow[t]{3}{*}{3} & & Wall P8 & & 4.95 & 0.40 & 3.60 & 1.80 & $2 \times 16.02$ & & 2195.06 \\
\hline & & Wall P10 & & 5.95 & 0.40 & 3.60 & 1.80 & $2 \times 19.62$ & & 2688.33 \\
\hline & & Wall P12 & & 7.25 & 0.40 & 2.05 & 3.64 & $2 \times 11.22$ & & 1537.71 \\
\hline
\end{tabular}

TABLE 6 | Costs of the insulation of walls.

\begin{tabular}{|c|c|c|c|c|c|c|c|c|}
\hline \multirow[t]{2}{*}{ Activity } & \multirow[t]{2}{*}{ Measurement unit } & \multicolumn{4}{|c|}{ Dimensions } & \multirow[t]{2}{*}{ Quantity $\left[\mathrm{m}^{2}\right]$} & \multicolumn{2}{|c|}{ Price } \\
\hline & & Length [m] & Thickness [m] & Height [m] & Openings $\left[\mathrm{m}^{2}\right]$ & & Unitary [Euro] & Total [Euro] \\
\hline Scaffolding & $\mathrm{m}^{2}$ & 56.60 & - & 7.55 & - & 427.33 & 17.62 & 7529.55 \\
\hline Aluminium profiles & m & 56.60 & 0.12 & - & - & 56.60 & 11.79 & 667.31 \\
\hline EPS sheets & $\mathrm{m}^{2}$ & 56.60 & 0.08 & 7.55 & 49.24 & 378.09 & 50.18 & 18972.56 \\
\hline Plaster & $\mathrm{m}^{2}$ & 56.60 & 0.02 & 7.55 & 49.24 & 378.09 & 18.09 & 6839.65 \\
\hline
\end{tabular}


abrasions and deformations. Besides performing an insulating function, panels are also excellent reinforcing elements for the architectural elements, making building more stable and safe. They are light, easy to be applied and work also as acoustic isolation systems.

In the current application on the existing residential building, the first phase consists in the dismantling of the existing roof cladding for the subsequent installation of the steel support structure. Subsequently, insulation panels are fixed to the support by mechanical connectors with orientation depending on the roof slope or the prevailing wind direction. Once fixing of the panels is finished, the roof insulation system can be considered as completed. With this intervention, the transmittance value " $U$ " $\left[\mathrm{W} / \mathrm{m}^{2} \mathrm{~K}\right]$ passes from $\mathrm{U}_{0}=0.52 \mathrm{~W} / \mathrm{m}^{2} \mathrm{~K}$ for the URM building to $\mathrm{U}_{1}=0.23 \mathrm{~W} / \mathrm{m}^{2} \mathrm{~K}$ for the retrofitted building, showing a decrease of $55.70 \%$.

\section{ECONOMIC EVALUATION AND TAX INCENTIVES \\ Cost Analysis}

In this section a cost analysis of previously described seismic and energetic upgrading interventions is performed. Seismic upgrading interventions cost is $€ 12780.00$ (Table 4), while seismic retrofitting interventions one is about $€ 75298.16$ (Table 5). On the other hand, the estimated costs for energetic interventions on walls and roof are $€ 43865.88$ (Table 6) and $€$ 17327.92 (Table 7), respectively. All the computed costs refer to the official price list for public works of the Campania Region of Italy (Italian Resolution of the Campania Regional Counciln 359/2016, 2016).

\section{Italian Government Deductions}

Referring to costs sustained for seismic and energetic requalification interventions, tax advantages provided by the Italian Government are herein examined. With regard to the seismic upgrading, the "Sismabonus" tool [35] allows to receive a tax detraction up to $€ 96000.00$ in 5 years depending on reduction of the number of seismic classes. Therefore, the seismic classification of the building before and after the interventions is needed. To this purpose, the main parameters to be evaluated are the average annual loss (Italian PAM acronym) and the seismic safety index (IS-V) (Cosenza et al., 2018).

For the PAM index calculation, it is necessary to make a diagram showing the expected damage during the building life in terms of economic losses (EL) vs. the exceeding annual average frequency $\left(\lambda=1 / T_{R}\right)$ (Figure 11). Therefore, the PAM index is

TABLE 7 | Costs of the roof insulation.

\begin{tabular}{|c|c|c|c|c|c|c|c|c|}
\hline Activity & Measurement unit & \multicolumn{4}{|c|}{ Dimensions } & Quantity $\left[\mathrm{m}^{2}\right]$ & \multicolumn{2}{|c|}{ Price } \\
\hline Roof disassembly & $\mathrm{m}^{2}$ & 31.30 & 6.75 & 6.75 & - & 211.28 & 6.26 & 1322.58 \\
\hline Steel box & $\mathrm{Kg}$ & - & - & - & - & 1912.35 & 3.03 & 5794.42 \\
\hline Insulated panels & $\mathrm{m}^{2}$ & 31.30 & 0.08 & 6.75 & - & 211.28 & 48.33 & 10210.92 \\
\hline
\end{tabular}

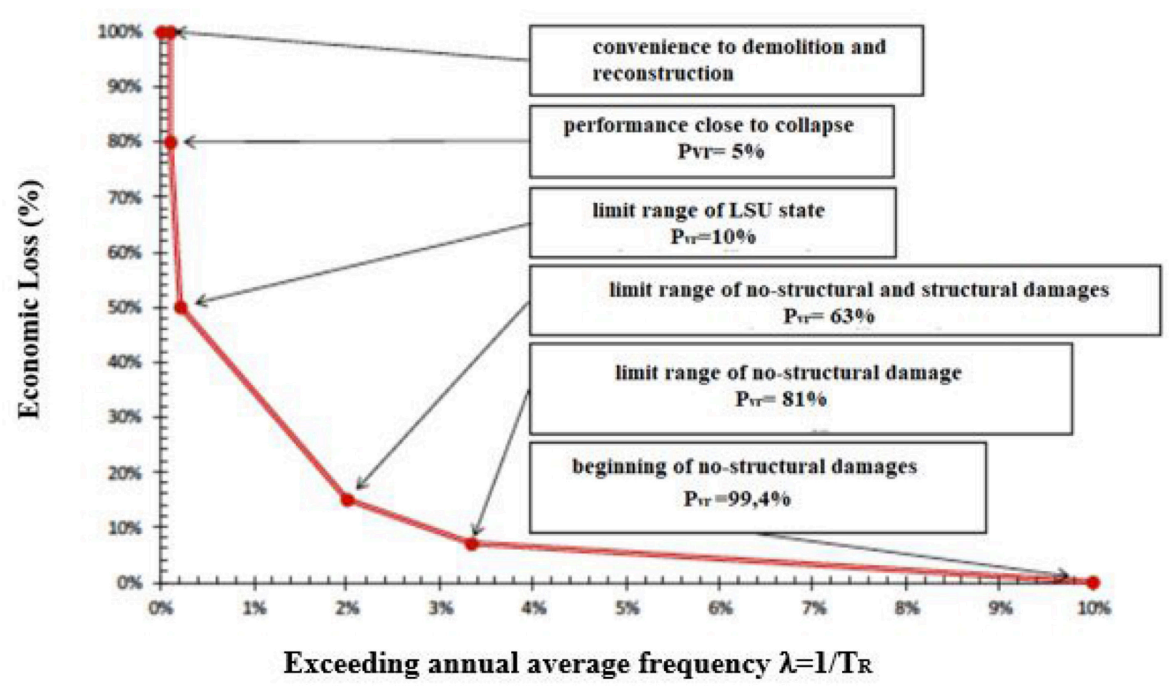

FIGURE 11 | The PAM index diagram. 
the area below the segments passing by the points identified in the diagram $(\lambda / \mathrm{EL})$.

Different steps occur for the calculation of the PAM index. First, the seismic analysis of the structure according to the Italian code NCT2018 is carried out and PGA values for each Limit State are considered. Subsequently, earthquake return periods $\left(T_{R}\right)$ can be calculated by the formula:

$$
\mathrm{T}_{\mathrm{RC}}=\mathrm{T}_{\mathrm{RD}}\left(\mathrm{PGA}_{\mathrm{C}} / \mathrm{PGA}_{\mathrm{D}}\right)^{\eta}
$$

where the subscripts C and D mean capacity and demand, respectively, while $\eta$ is calculated as follows:

$$
\begin{aligned}
1 / 0.49 & \text { for } a_{\mathrm{g}}>0.25 g \\
1 / 0.43 & \text { for } 0.25 g<a_{\mathrm{g}}<0.15 g \\
1 / 0.356 & \text { for } 0.15 g<a_{\mathrm{g}}<0.05 g \\
1 / 0.34 & \text { for } 0.05 g<a_{\mathrm{g}}
\end{aligned}
$$

So, for each return period, a value of the exceeding annual average frequency $\left(\lambda=1 / \mathrm{T}_{\mathrm{R}}\right)$ can be determined. In Figure 6

TABLE 8 | PAM classes.

\begin{tabular}{ll}
\hline Annual loss (PAM) & Class \\
\hline $\mathrm{PAM} \leq 0.50 \%$ & $\mathrm{~A}+$ \\
$0.50 \%<\mathrm{PAM} \leq 1 \%$ & $\mathrm{~A}$ \\
$1 \%<\mathrm{PAM} \leq 1.5 \%$ & $\mathrm{~B}$ \\
$1.5 \%<\mathrm{PAM} \leq 2.5 \%$ & $\mathrm{C}$ \\
$2.5 \%<\mathrm{PAM} \leq 3.5 \%$ & $\mathrm{D}$ \\
$3.5 \%<\mathrm{PAM} \leq 4.5 \%$ & $\mathrm{E}$ \\
$4.5 \%<\mathrm{PAM} \leq 7.5 \%$ & $\mathrm{~F}$ \\
$7.5 \%<\mathrm{PAM}$ & $\mathrm{G}$
\end{tabular}

TABLE 9 | IS-V classes.

\begin{tabular}{ll}
\hline Life safety index (IS-V) & Class \\
\hline $100 \%<$ IS-V & $\mathrm{A}+$ \\
$80 \%<I S-V \leq 100 \%$ & $\mathrm{~A}$ \\
$60 \%<$ IS-V $\leq 80 \%$ & $\mathrm{~B}$ \\
$45 \%<I S-V \leq 60 \%$ & $\mathrm{C}$ \\
$30 \%<I S-V \leq 45 \%$ & $\mathrm{D}$ \\
$15 \%<I S-V \leq 30 \%$ & $\mathrm{E}$ \\
IS-V $\leq 15 \%$ & $\mathrm{~F}$
\end{tabular}

TABLE 10 | Reconstruction cost percentage value associated to each Limit State.

\begin{tabular}{lc}
\hline Limit state & CR(\%) \\
\hline SLR & 100 \\
SLC & 80 \\
SLV & 50 \\
SLD & 15 \\
SLO & 7 \\
SLID & 0
\end{tabular}

there are 6 limit states ranging from "beginning of nostructural damage," associated to a zero economic loss after a seismic event with a return period conventionally assumed equal to 10 years $(\lambda=0.1)$, to "convenience to demolition and reconstruction," associated to a $100 \%$ economic loss, where the building shows the impossibility to have upgrading interventions. The resulting eight PAM classes are identified in Table 8.

On the other hand, the IS-V life safety index is the ratio between the PGA referred to the ULS and the PGA demand. The seven IS-V classes are identified in Table 9.

The structure risk class is the worst between the PAM class and the IS- $\mathrm{V}$ one.

It is possible to receive a tax detraction of $50 \%$ if seismic upgrading left unaltered the seismic risk, of $70 \%$ if seismic risk is reduced of one class and of $80 \%$ if seismic risk is decreased of two or more classes.

More in detail, in order to evaluate PAM and IS-V classes there are two procedures, namely a conventional method and a simplified one. The conventional method is commonly developed by structural calculation programs and is developed in the following steps:

1. The structure analysis is carried out and the capacity acceleration values $\mathrm{PGA}_{\mathrm{C}}\left(\mathrm{LS}_{\mathrm{i}}\right)$, which induce the achievement of predefined limit states (collapse SLC, life safety SLV, damage SLD and operational SLO) indicated by the Italian standard [7], are determined.

2. From each $\mathrm{PGA}_{\mathrm{C}}$ value it is possible to determine the corresponding return period value " $\mathrm{T}_{\mathrm{RC}}$ " from Equation (1).

3. For each period identified by Equation (6), the exceeding annual average frequency value $\lambda$ is determined as $1 / \mathrm{T}_{\mathrm{RC}}$.

4. The Initial Damage Limit State (SLID) is defined as the state where no economic loss is attained with reference to an earthquake having $\mathrm{T}_{\mathrm{RC}}=10$ years, i.e., $\lambda=0.1$.

5. The Reconstruction Limit State (SLR) is defined as the state corresponding to an economic loss of $100 \%$, where demolition and reconstruction of the building is the only possible choice.

6. For each limit states considered, Table 10 shows reconstruction cost percentage values $\left(\mathrm{CR}_{\%}\right)$ associated to the corresponding values of $\lambda$.

7. The PAM (in percentage value), that is the area subtended to the curve of Figure 11 identified by points $\left(\lambda_{\mathrm{i}}, \mathrm{CR}_{\mathrm{i}}\right)$ for each of the considered limit states, is calculated as follows:

$$
\begin{aligned}
& \mathrm{PAM}=\Sigma_{\mathrm{i}=2}^{5}\left[\lambda\left(\mathrm{SL}_{\mathrm{i}}\right)-\lambda\left(\mathrm{SL}_{\mathrm{i}-1}\right)\right]^{*}\left[\mathrm{CR}\left(\mathrm{SL}_{\mathrm{i}}\right)+\mathrm{CR}\left(\mathrm{SL}_{\mathrm{i}-1}\right)\right] / 2 \\
& +\lambda(S L C)^{*} C R(S L R)
\end{aligned}
$$

8. Based on the PAM value obtained, the PAM class is identified through Table 8.

9. The IS-V index, that is the ratio between the $P_{G A}$ (capacity) and $\mathrm{PGA}_{\mathrm{D}}$ (demand) at the Life Safety limit state, is determined.

10. The IS-V class is identified through Table 9.

11. The structure Risk Class is identified as the worst between the PAM class and the IS-V one. 
The Risk Class value can be improved by retrofitting or upgrading interventions, which reduce the seismic risk of the construction.

For masonry structures a simplified method can be used instead of the conventional one. In particular, Risk Class is determined starting from the identification of one of vulnerability classes defined by the European Macro-Seismic Scale (EMS) in Figure 12.

EMS-98 identifies 7 types of structures and 6 average vulnerability classes (from $\mathrm{V}_{1}$ to $\mathrm{V}_{6}$ ) with increasing vulnerability from 1 to 6. As illustrated in Figure 12, for each structure type, the most credible vulnerability class is individuated by a circle, while the more probable class and the less probable one are identified by continuous lines and dotted lines, respectively.

Vulnerability class corresponds to a Class of Risk. Therefore, once the seismic zone is defined and the vulnerability class $\left(\mathrm{V}_{\mathrm{i}}\right)$ of the building is known, its Risk Class is identified, as shown in Table 11. In this table it is observed that the classes attributed with the simplified method are marked with an asterisk $\left(A_{+}^{*}, A^{*}\right.$, $\mathrm{B}^{*}$, etc.) in order to be distinguishable from those obtained with the conventional method.

In the examined case study, the risk class of the original building, obtained using the conventional method foreseen by the 3Muri software, is C. Seismic upgrading interventions allows to obtain the class $\mathrm{B}$, while seismic retrofitting decreases two Risk Classes, attaining the class A. As a consequence, it is possible to receive a tax detraction of 70 and $80 \%$ in case of seismic upgrading and seismic retrofitting, respectively.

On the other hand, considering energetic upgrading interventions, the "Ecobonus" tool [Lawn 205 of 27/12/17, 2017] allows to obtain a tax deduction of the sustained costs (to be received in 10 years) equal to $65 \%$. The main parameter is the energetic performance index, indicated as EP. There are 10 classes, from A4 to G, with increasing values of EP. A building is classified according to the possible reference energy classes (A4, A3, A2, A, B, C, D, E, F, G) based on energy which needs for winter heating, expressed in $\mathrm{kWh} /$ year for square meter of surface or in $\mathrm{kWh} /$ year for cubic meter of volume. The factors used to calculate this index are numerous and they depend on the type of heating system and on materials used for walls, windows, and roofs.

Table 12 shows the annual tax detractions due to the application of both bonuses.

Finally, in order to compare intervention costs to tax detractions offered by the Italian Government, a global performance index " $\mathrm{I}_{\mathrm{GP}}$ " can be formulated as follows:

$$
I_{G P}=\frac{I_{S}+I_{E}}{I_{s} \cdot \varnothing_{S}+I_{E} \cdot \varnothing_{E}}
$$

where:

$$
\varnothing_{S}, \varnothing_{E}=\frac{\text { Total tax detraction }}{\text { Total cost }}
$$

TABLE 11 | Risk classes attributed from vulnerability classes.

\begin{tabular}{llllll}
\hline Risk class & PAM & Zone 1 & Zone 2 & Zone 3 & Zone 4 \\
\hline$A^{*}$ & PAM $\leq 0.50 \%$ & & & & $V_{1} \div V_{2}$ \\
$A^{*}$ & $0.50 \%<P A M \leq 1 \%$ & & & $V_{1} \div V_{2}$ & $V_{3} \div V_{4}$ \\
$B^{\star}$ & $1 \%<P A M \leq 1.5 \%$ & $V_{1}$ & $V_{1} \div V_{2}$ & $V_{3}$ & $V_{5}$ \\
$C^{*}$ & $1.5 \%<P A M \leq 2.5 \%$ & $V_{2}$ & $V_{3}$ & $V_{4}$ & $V_{6}$ \\
$D^{*}$ & $2.5 \%<P A M \leq 3.5 \%$ & $V_{3}$ & $V_{4}$ & $V_{5} \div V_{6}$ & \\
$E^{*}$ & $3.5 \%<P A M \leq 4.5 \%$ & $V_{4}$ & $V_{5}$ & & \\
$F^{*}$ & $4.5 \%<P A M \leq 7.5 \%$ & $V_{5}$ & $V_{6}$ & & \\
$G^{*}$ & $7.5 \%<P A M$ & $V_{6}$ & & &
\end{tabular}

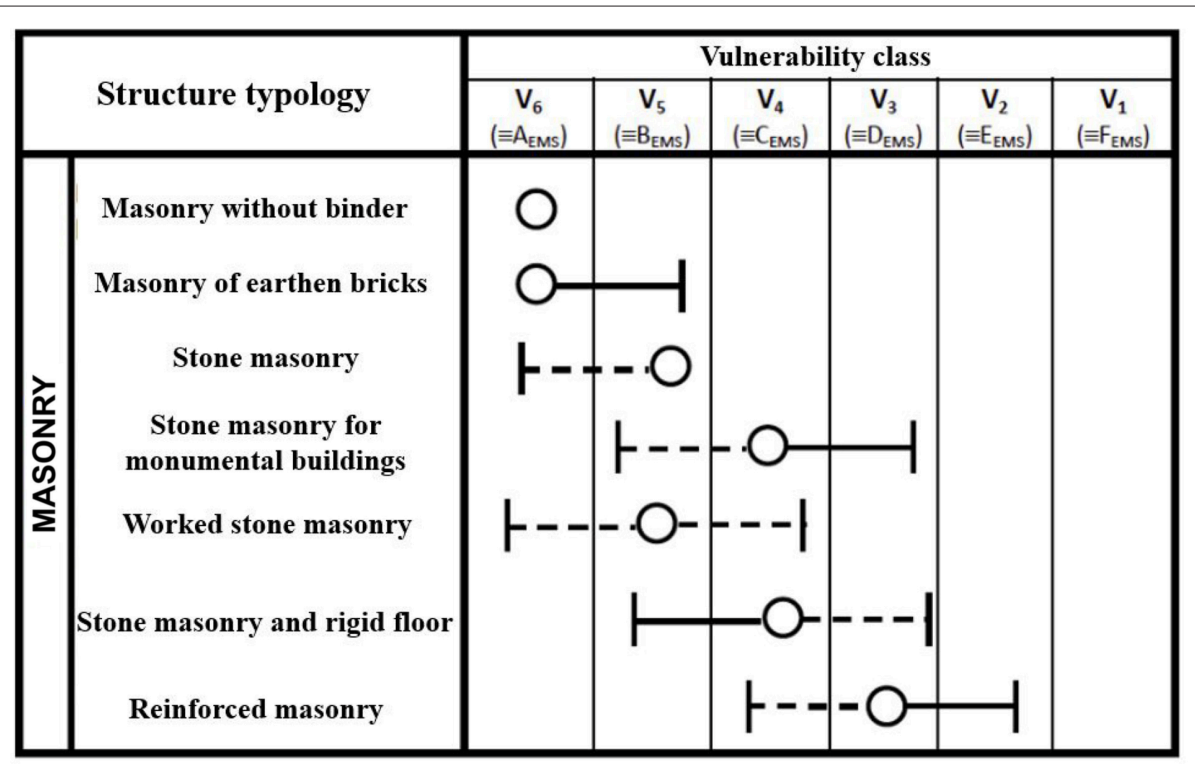

FIGURE 12 | Simplified approach for the masonry Vulnerability Class attribution. 
TABLE 12 | Italian Government incentives for seismic and energetic interventions.

\begin{tabular}{|c|c|c|c|c|}
\hline Intervention & Incentive & Total cost (Euro) & Total tax detraction (Euro) & Annual tax detraction (Euro) \\
\hline Seismic upgrading & Sismabonus & 12780.00 & 8946.00 & 1789.20 \\
\hline Seismic retrofitting & & 75298.16 & 60238.53 & 12051.71 \\
\hline Energetic upgrading & Ecobonus & 61193.80 & 39775.97 & 3977.60 \\
\hline
\end{tabular}

are coefficients taking into account the more or less benefits of received incentives, while " $\mathrm{I}_{\mathrm{S}}$ " and " $\mathrm{I}_{\mathrm{E}}$ " are referred to seismic upgrading and energetic one, respectively, according to the following relationships:

$$
I_{S}=1-\frac{P A M}{P A M_{\max }} ; I_{E}=1-\frac{E P}{E P_{\max }}
$$

where the subscript "max" indicates the maximum value achievable for the average annual loss (PAM) and the energetic performance (EP) indices.

Optimal values of " $\mathrm{I}_{\mathrm{GP}}$ " should be close to one. If " $\mathrm{I}_{\mathrm{GP}}$ " is $>1$, intervention costs are excessive compared to the tax detraction that could be received, while if " $\mathrm{I}_{\mathrm{GP}}$ " is lower than one, there is not a full exploiting of bonuses offered.

In conclusion, the proposed index could represent a very useful tool to evaluate the economic benefits deriving from combined energetic-seismic interventions applied on residential buildings. However, the reliability of the proposed formulation should be proved by further investigations on some other case studies, which represent the future development of the current research activity.

\section{CONCLUSIONS}

In this paper a seismic, energetic and economic combined procedure for upgrading residential masonry buildings is proposed. Proper seismic and energetic interventions have been designed and applied to a case study of a masonry building placed in Venticano (province of Avellino, Italy). From the seismic viewpoint, since the URM building has shown a

\section{REFERENCES}

Aste et al., 2012 Aste, N., Adhikari, R., and Buzzetti, M. (2012). Energy retrofit of historical buildings: an italian case study. J. Green Build. 7, 144-165. doi: 10.3992/jgb.7.4.144

Bertolesi, E., Fabbrocino, F., Formisano, A., Grande, E., and Milani, G. (2017). FRP-strengthening of curved masonry structures: local bond behaviour and global response. Key Eng. Mater. 747, 134-141. doi: 10.4028/www.scientific.net/KEM.747.134

Brando, G., De Matteis, G., and Spacone, E. (2017). Predictive model for the seismic vulnerability assessment of small historic centres: application to the inner abruzzi region in Italy. Eng. Struct. 153, 81-96. doi: 10.1016/j.engstruct.2017.10.013

Cecchi, R., and Calvi, M. (2010). Guidelines for Evaluation and Mitigation of Seismic Risk to Cultural Heritage with Reference to Technical Standard for Construction (In Italian). Ministry for Cultural Heritage and Activities, Department of Civil Protection Agency, ed (Gangemi, G), Rome, Italy. deficient behavior ( $\alpha_{\text {ULS }}$ equal to 0.61 and 0.65 in the directions $\mathrm{X}$ and $\mathrm{Y}$, respectively), seismic upgrading interventions with reinforced plaster have been foreseen, they allowing for a slight increase $(<10 \%)$ of the seismic safety factors detected for the original building. Therefore, considering the slight increase of performance deriving from seismic upgrading, retrofitting interventions have been also considered. In this case, pushover analyses have provided $\alpha_{U L S}$ values $>1$, with lowest values of 1.18 and 1.99 in directions $\mathrm{X}$ and $\mathrm{Y}$, respectively. This has allowed to obtain a minimum growth of the $\alpha_{U L S}$ coefficient equal to 39.30 and $119.01 \%$ in directions $\mathrm{X}$ and $\mathrm{Y}$, respectively, with respect to the analogous factors computed for the URM building.

Energetic upgrading interventions based on thermal insulation of walls and roof have allowed to reduce the transmittance values of 81.70 and $55.70 \%$, respectively. The proposed interventions have been quantified in terms of costs and tax detractions due to the Italian Government incentives (Sismabonus and Ecobonus). In particular, the total tax detractions (eligible in 5 years) related to upgrading interventions and retrofitting ones have been estimated as equal to $€ 8946.00$ and $€ 60238.53$, respectively, while for energetic upgrading works a tax benefit of $€ 39775.97$ to be received in 10 years has been obtained.

Finally, a global performance index able to assess the more or less convenience in exploiting the considered incentives has been proposed.

\section{AUTHOR CONTRIBUTIONS}

AF elaborated the paper guidelines. GV prepared the paper draft. FF corrected the paper.

Clementi, F., Pierdicca, A., Formisano, A., Catinari, F., and Lenci, S. (2017). Numerical model upgrading of a historical masonry building damaged during the 2016 Italian earthquakes: the case study of the Podesta' palace in Montelupone (Italy). J. Civ. Struct. Health Monit. 7, 703-717. doi: 10.1007/s13349-017-0253-4

Clementi, F., Pierdicca, A., Milani, G., Gazzani, V., Poiani, M., and Lenci, S. (2018). "Numerical model upgrading of ancient bell towers monitored with a wired sensors network," in Proceedings of the 10th International Masonry Conference, (Milan).

Cosenza, E., Del Vecchio, C., Di Ludovico, M., Dolce, M., Moroni, C., Prota, A., and Renzi, E. (2018). The Italian guidelines for seismic risk classification of constructions: technical principles and validation. Bull Earthquake Eng. 16, 5905-5935. doi: 10.1007/s10518-0180431-8

D’Agostino, N., Mantenuto, S., D’Anastasio, E., Avallone, A., Barchi, M., Collettini, C., et al. (2009). Contemporary crustal extension in the Umbria-Marche Apennines from regional CGPS networks and comparison 
between geodetic and seismic deformation. Tectonophysics 476, 3-12. doi: $10.1016 /$ j.tecto.2008.09.033

Formisano, A. (2014). "Seismic behaviour and retrofitting of a school masonry building subject to the 2012 Emilia-Romagna Earthquake," in Civil-Comp Proceedings (Naples), 106.

Formisano, A. (2017). Theoretical and numerical seismic analysis of masonry building aggregates: case studies in San Pio Delle Camere (L'Aquila, Italy). J. Earthq. Eng. 21, 227-245. doi: 10.1080/13632469.2016.1172376

Formisano, A., and Marzo, A. (2017). Simplified and refined methods for seismic vulnerability assessment and retrofitting of an Italian cultural heritage masonry building. Comput. Struct. 180, 13-26. doi: 10.1016/j.compstruc.2016. 07.005

Fumo, M., Formisano, A., Violano, A., and Sibilio, G. (2018). Energy and seismic recovering of ancient hamlets: the case of Baia e Latina. Sustainability 10:2831. doi: 10.3390/su10082831

Italian Ministers Council Presidency Decree (DPCM) (2011). Guidelines for Evaluation and Reduction of the Cultural Heritage Seismic Risk With Reference to the Technical Codes for Constructions of Which to the 2008 Ministry of Infrastructures and Transport Decree (in Italian), Italy.

Italian Ministry of Infrastructures and Transports (2008). Ministerial Decree 14 January 2008 "Technical Codes for Constructions" (in Italian). Official Gazette n. 29.

Italian Ministry of Infrastructures and Transports (2009). Ministerial Circular 2 February 2008 "Instructions for the Application of New Technical Codes for Constructions" (in Italian). Official Gazette n. 47.

Italian Ministry of Infrastructures and Transports (2018). Ministerial Decree 17 January 2018, Updating of Technical Codes for Constructions (in Italian). Official Gazette n. 42, Ordinary Supplement n. 8 .

Italian Resolution of the Campania Regional Counciln 359/2016 (2016). Department of Territorial Policies, Directorate General for Public Works and Civil Protection, Regional Price List for Public Works in the Campania Region (in Italian).

Jung, D. K., Lee, D. H., Shin, J. H., Byung, H. S., and Park, S. H. (2013). Optimization of energy consumption using bim based building energy performance analysis. Appl. Mech. Mater. 281, 649-652. doi: 10.4028/www.scientific.net/AMM.281.649

Krstevska, L., Tashkov, L., Naumovski, N., Florio, G., Formisano, A., Fornaro, A., et al. (2010). "In-situ experimental testing of four historical buildings damaged during the 2009 L' Aquila earthquake, in COST ACTION C26: Urban Habitat Constructions under Catastrophic Events," in Proceedings of the Final Conference, (Naples), 427-432.

Lawn., 205 of 27/12/17 (2017). Balance Law 2018, Official Gazette n. 302 of 29/12/17, Ordinary Supplement n 62 (in Italian).

Marghella, G., Marzo, A., Carpani, B., Indirli, M., and Formisano, A. (2016). "Comparison between in situ experimental data and Italian code standard values, in Brick and Block Masonry: trends, Innovations and Challenges," in Proceedings of the 16th International Brick and Block Masonry Conference, IBMAC (Padua), 1707-1714.

Michele, M., Di Stefano, R., Chiaraluce, L., Cattaneo, M., De Gori, P., Monachesi, G., et al. (2016). The Amatrice 2016 seismic sequence: A preliminary looks the main shock and aftershocks distribution. Ann. Geophys. 59:5. doi: 10.4401/ag-7227

Mosoarca, M., Apostol, I., Keller, A., and Formisano, A. (2017). Consolidation methods of Romanian historical building with composite materials.
Key Eng. Mater. 747, 406-413. doi: 10.4028/www.scientific.net/KEM. 747.406

Quagliarini, E., Maracchini, F., and Clementi, F. (2017). Uses and limits of the equivalent frame model on existing unreinforced masonry buildings for assessing their seismic risk: a review. J. Build. Eng. 10, 166-182. doi: 10.1016/j.jobe.2017.03.004

Ramaglia, G., Lignola, G. P., Fabbrocino, F., and Prota, A. (2018). Numerical investigation of masonry strengthened with composites. Polymers 10:334. doi: $10.3390 /$ polym 10030334

Rapone, D., Brando, G., Spacone, E., and De Matteis, G. (2018). Seismic vulnerability assessment of historic centers: description of a predictive method and application to the case study of Scanno (Abruzzi, Italy). Int. J. Archit. Heritage 12, 1171-1195. doi: 10.1080/15583058.2018.1503373

Roberts, S., and Stephenson, R. (2012). Measure Guideline: Wall Air Sealing and Insulation Methods in Existing Homes. U.S. Department of Energy, Energy Efficiency and Renewable Energy, Oak Ridge, USA. Available online at: https:// www.nrel.gov/docs/fy12osti/55480.pdf

S.T.A.DATA (2016). 3MURI - Seismic Calculation of Masonry Structures According to the Italian Ministerial Decree 20/02/18 "Updating of Technical Codes for Constructions (in Italian)."

Tashkov, L., Krstevska, L., Naumovski, N., De Matteis, G., and Brando, G. (2010). "Ambient vibration tests on three religious buildings in Goriano Sicoli damaged during the 2009 L'Aquila earthquake, in COST ACTION C26: Urban Habitat Constructions under Catastrophic Events," in Proceedings of the Final Conference (Naples), 433-438.

Ubertini, F., Cavalagli, N., Kita, A., and Comanducci, G. (2018). Assessment of a monumental masonry bell-tower after 2016 Central Italy seismic sequence by long-term SHM. Bull. Earthq. Eng. 16, 775-801. doi: 10.1007/s10518-017-0222-7

Ubertini, F., Comanducci, G., Cavalagli, N., Pisello, A. L., Materazzi, A. L., and Cotana, F. (2017). Environmental effects on natural frequencies of the San Pietro bell tower in Perugia, Italy, and their removal for structural performance assessment. Mech. Syst. Signal Process. 82, 307-322. doi: 10.1016/j.ymssp.2016.05.025

Ueno, K., and Van Straaten, R. (2012). Expert Meeting Report: Interior Insulation Retrofit of Mass Masonry Wall Assemblies, U.S. Department of Energy, Energy Efficiency and Renewable Energy, Oak Ridge, USA. Available online at: https:// www.nrel.gov/docs/fy12osti/53496.pdf

Xu, Z., Guan, X., Jia, Q., Wu, J., Wang, D., and Chen, S. (2012). Performance analysis and comparison on energy storage devices for smart building energy management. Smart Grid IEEE Transac. 3, 2136-2147. doi: $10.1109 /$ TSG.2012.2218836

Conflict of Interest Statement: The authors declare that the research was conducted in the absence of any commercial or financial relationships that could be construed as a potential conflict of interest.

Copyright (C) 2019 Formisano, Vaiano and Fabbrocino. This is an open-access article distributed under the terms of the Creative Commons Attribution License (CC BY). The use, distribution or reproduction in other forums is permitted, provided the original author(s) and the copyright owner(s) are credited and that the original publication in this journal is cited, in accordance with accepted academic practice. No use, distribution or reproduction is permitted which does not comply with these terms. 